\title{
Acid neutralizing capacity, an important waste management parameter
}

https://doi.org/10.21698/rjeec.2020.220

Proceedings Paper

\author{
GEORGIANA CERNICA, GINA ALINA CATRINA, GEORGETA MADALINA ARAMA*, \\ AGNES SERBANESCU, ADRIANA CUCIUREANU, BOGDAN STANESCU
}

National Research and Development Institute for Industrial Ecology - ECOIND, 71-73 Drumul Podul Dambovitei, 060652, Bucharest, Romania

*Corresponding author (e-mail): madalina.arama@incdecoind.ro

\begin{abstract}
The paper presents the influence of acid neutralization capacity in industrial waste samples as a decision indicator. For the analysis of the acid neutralization capacity, six samples of wastes from different sectors of activity were subjected. A successful method that can be applied to determine the properties of waste is acidneutralizing capacity. The acid-neutralizing capacity was evaluated with $\mathrm{HCl} 1 \mathrm{~N}$ by neutralizing the excess with $\mathrm{NaOH} 0.5 \mathrm{~N}$ after 15 min stirring. From the results obtained it is found that the acid neutralization capacity can provide essential information for the subsequent management of the waste.
\end{abstract}

Keywords: acid-neutralizing capacity, industrial waste, soil

\section{INTRODUCTION}

Waste management is important in this century because of the increase in industrialization and global population. Until 2100, waste generation is expected to triple globally [1]. The different chemical industries such as refineries, pharmaceuticals, and textiles use water, solvents, and polymers to reach hazardous waste. They can generate a large amount of hazardous organic waste [2]. Due to the large amounts of waste generated, it is becoming difficult to place new storage facilities. That is why an important issue is to develop new strategies for reducing the volume of waste [3]. Also, waste management is considered an activity of public interest carried out following the provisions of this law and the regulations adopted under this law. A good analysis, which gives us information's about waste material of the field, is the acid-neutralizing capacity (ANC). When hazardous waste is wanted to be deposited in a landfill for non-hazardous wastes, the law says that it must be a stable nonreactive waste. The definition of a stable waste implies that "the leaching behavior of the waste will not change adversely under some weather conditions such as temperature, air, water" $[4$, 5]. As the solubility of the species (metallic compounds) increases with a $\mathrm{pH}$ decrease, a stabilized-solidified hazardous waste will be more "stable" when having enough buffering capacity. A representative measure of the total buffering capacity against acidification for a solution is ANC parameter. This parameter can also be defined as the difference between the bases and anions of strong acids. Thus it can be characterized as the amount of acid needed to change the $\mathrm{pH}$ value from the initial value to a chosen one. The ability to neutralize acids can provide us information on several properties of waste $[6,7]$, such as determination of the waste material behavior, this property is important to understand the influence to the environment (a concrete example could be the interaction of the waste with leachate or other materials). The waste from a landfill should have a $\mathrm{pH}$ as neutral as possible around $7-8$, in order not to produce adverse effects for a long period or to not harm the environment. One problem that can be encountered is that the waste cannot be neutralized due to the reactions between the wastes. Then use acidic or alkaline leachate which can produce neutralizing effects. Examples of such effects may be acid rain, anaerobic or aerobic digestion, etc. The cause of adverse effects may be due to high $\mathrm{pH}$ values or low $\mathrm{pH}$ values [8]. The ANC cannot be evaluated for an entire field, and also can`t be established an exact $\mathrm{pH}$, therefore the analysis of unique materials is made and taking into account the information and conditions of the field for interpretation. As conditions can be the construction of the field, the waste flow, the storage conditions, and their management. According to Romanian Order no. 95/2005, 
granular waste must meet the following additional criteria: the TOC must not exceed $5 \%$, the $\mathrm{pH}$ must be at least 6.0 and the ANC must be evaluated [9]. ANC of waste material could be determined by several methods. In this

\section{EXPERIMENTAL PART}

\section{Equipment}

Calcination furnace SNOL 10/1300 LHM01, Drying oven Thermo Scientific Heratherm A P,

\section{Reagents and materials}

$\mathrm{HCl} 1 \mathrm{~N}$, Merck quality; $\mathrm{NaOH} 0.5 \mathrm{~N}$, Merck

\section{Method applied}

The ANC of a sample is represented by the amount of acid consumed taking into account the fixed test conditions.

The preparation of the test consists of the first step: the sample was dried and sieved, a granulation less than $1 \mathrm{~mm}$ particle size in proportion of $95 \%$ was retained. If the mass of the oversized material exceeds $5 \%$ of the total, the waste must be crushed [10].

There are other cases where the material cannot be crushed (e.g. screws, nuts) and then the nature of the material must be recorded, removed and the mass must be weighed. In the end, the sieved material and the one that could not be crushed must be taken into account to constitute the mass of the complete waste

$$
A N C=\frac{\left(N_{H C l} * V_{H C l}\right)-\left(N_{N a O H} * V_{N a O H}\right)}{M_{W}}
$$

where $A N C$ is the acid-neutralizing capacity (mol H$H^{+} / \mathrm{kg}$ s.u.), $N_{\mathrm{HCl}}$ and $N_{\mathrm{NaOH}}$ are the normal concentrations of reagents $(\mathrm{mol} / \mathrm{L}), V_{\mathrm{HCl}}$ and

\section{Waste samples}

All waste samples were analyzed in the same way and also the samples come from industrial waste. case, the ANC is determined through titration to a selected $\mathrm{pH}$ value.

The purpose of the study was to determine and evaluate the ANC parameter from a different type of waste samples.

magnetic stirrer Velp Scientifica, ROTH Rotilabo sieve, $\varnothing 200 \mathrm{~mm}$, mesh size $1 \mathrm{~mm}$.

quality.

material. A second important aspect to take into consideration is the dry matter content because it will be used to establish the final result.

After we had the samples ready, we weigh 5 grams and transfer them to an Erlenmeyer glass. Add $50 \mathrm{ml}$ of water (in a 1:10 ratio) and stir on the magnetic stirrer for $1 \mathrm{~min}$. Then add a few drops of indicator (methyl red) and $30 \mathrm{~mL}$ of $\mathrm{HCl} 1 \mathrm{~N}$ over a $15 \mathrm{~min}$ interval, stirring constantly. After stirring, the excess of $\mathrm{HCl}$ is titrated with $\mathrm{NaOH} 0.5 \mathrm{~N}$ while maintaining a stable $\mathrm{pH}$ of 3.5 . The test method applied to estimate ANC parameter was according to in force legislation [11].

To reach the final result the following equation was used (1):

$V_{\mathrm{NaOH}}$ are the volumes of reagents $(\mathrm{ml})$, and $M_{w}$ is the amount of waste $(\mathrm{g})$.

In Table 1 are presented some characteristics and types of analyzed waste.

Table 1. Waste samples, origin, and $\mathrm{pH}$

\begin{tabular}{c|ccc}
\hline Samples & Type & $\begin{array}{c}\text { Dry residue } \\
(\%)\end{array}$ & $\mathrm{pH}$ \\
\hline D1 & waste generated from the roads, platforms & 96.06 & 11.0 \\
D2 & waste from administrative buildings & 95.66 & 10.6 \\
D3 & waste generated from the semi-buried tank & 93.09 & 10.7 \\
D4 & waste from tank, horizontal tanks; & 96.60 & 11.0 \\
D5 & waste from the ash hearth from the incineration plant & 89.98 & 10.4 \\
D6 & ceramic filter waste from the incineration gas filter system & 96.82 & 6.52 \\
\hline
\end{tabular}




\section{RESULTS AND DISCUSSION}

The calculation is performed according to the dry residue and the amount of consumed $\mathrm{mL}$ of hydrochloric acid. In Table 2 are presented the results obtained for all types of analyzed waste samples. From the obtained results, it is found that the highest concentrations were obtained at D2, D3, D4, and D5 samples, lower concentration was obtained D1 and D6 samples. These results show up the influence of the amount of acid consumed.

Table 2. Final results

\begin{tabular}{c|cccc}
\hline Samples & Initial $\mathrm{pH}$ & Final $\mathrm{pH}$ & $\begin{array}{c}\text { Amount of acid } \\
\text { consumed } \mathrm{HCl}(\mathrm{mL})\end{array}$ & $\begin{array}{c}\text { ANC } \\
\left(\mathrm{mol} \mathrm{H}^{+} / \mathrm{kg} \mathrm{s.u} .\right)\end{array}$ \\
\hline D1 & 11.0 & 3.45 & 43 & 1.76 \\
D2 & 10.6 & 3.50 & 31 & 2.77 \\
D3 & 10.7 & 3.48 & 40 & 1.86 \\
D4 & 11.0 & 3.46 & 41 & 1.74 \\
D5 & 10.4 & 3.49 & 35 & 1.52 \\
D6 & 6.52 & 3.50 & 58 & 0.19 \\
\hline
\end{tabular}

To evaluate ANC results, it is not easy to set limits in ANC for the type of waste that may be appropriate instead of individual wastes, the overall amount of waste contained in the landfill. $\mathrm{pH}$ is strongly dependent on the quantity of that particular waste relative to the main types of waste accepted at the landfill. However, when the ANC of waste is high, any contaminants, which depend on alkaline precipitation mechanism to remain insoluble, will not leach. Choosing the test procedure for ANC indicator is considered a better way to account for the resilience of landfilled waste to different chemical processes that can produce leachate acidification. Through assessment, the ANC, can be shown until what $\mathrm{pH}$ value the waste can have an "acceptable" buffer capacity to be protective for the environment (maintaining a relatively constant neutral $\mathrm{pH}$ ). Documents for applying current waste legislation for determining hazardous waste through HP4 property (corrosiveness) [12] - a property that can be developed within the landfill due to favorable conditions - advise evaluators the following: "test if the waste has a $\mathrm{pH}$ of 2 or less or a $\mathrm{pH}$ of 11.5 or more, or does leachate of the waste have such a $\mathrm{pH}$ and if the answer is yes, test if acid/alkali determined reserve indicates a low buffer capacity". If timely detected this can direct, towards pro-active measures and for better new waste deposition in the landfill, mitigating this way the trend for excessive acidification.

Consequently, ANC data are required for waste management. For e. g. wastes with high inorganic content are those that are to be disposed of on a certain type of landfill. Therefore, ANC data are necessary for their management. Some categories of wastes that may have a high content of inorganic matter are sludge from metallurgical waste, ash from energy production, slag, and ash.

Wastes that contain a high level of heavy metals must be evaluated for the influence of $\mathrm{pH}$ to ensure that the waste is acceptable for long-term storage. If the waste is disposed on a landfill and is in contact with other residual material, ANC testing is required. These are known for their general usual composition and their leaching behavior but that doesn't exclude testing each time when necessary.

That is necessary because the heterogeneity of such wastes is very high. These depend on the type of industrial processes they come from (different metals in different ranges of concentrations) and the specific climate and weather conditions within each landfill. Thus, commenting on our presented results from Table 1, a sample like D6 has a lower buffering capacity. Any changes in weather and landfill chemical-specific conditions can determine the move of $\mathrm{pH}$ form leachate from its neutral agreed environmental protective value towards lower values determining the dissolving of heavy metals. That is particularly the case e.g. if in the landfill there are wastes with a high level of heavy metals. This is the context in which the waste should be tested to see the influence of $\mathrm{pH}$ to ensure its long-term storage considering their chemical possible reactions 
with other waste materials that will be further disposed of during the active life of the corresponding considered landfill. So, the ANC

\section{CONCLUSIONS}

The ANC indicator needs to be evaluated by the landfill owner for all of the hazardous wastes entering the landfill or intended to enter the landfill.

To assessment, this indicator, some basic information about the waste is important, such as the generation process, $\mathrm{pH}$ value, and hazardous properties of the waste.

When the hazardous waste with high ANC value is deposited in a landfill for nonhazardous wastes, under the impact of longterm ambient conditions, this will have better

\section{ACKNOWLEDGEMENTS}

This work was carried out through the "Nucleu" Program (PN 190404 01/2019) financed by the

\section{REFERENCES}

[1] MINELGAITE, A., LIOBIKIENE, G., Sci. Total Environ., 667, 2019, p. 86.

[2] WORRALL, F., HOWDEN, N., BURT, T., BARTLETT, R., J. Hydrol., 556, 2018, p. 775.

[3] LI, W., ZENGYI, M., HUANG, Q., JIANG, X., Fuel., 233, 2018, p. 427.

[4] KIM, L., ARAMA, M. G., CUCIUREANU, A., GUTA, D., Environ. Eng. Manag. J., 17, 2018, p. 2945.

[5] ARAMA, M. G., PASCU, L. F., GUTA, D., International Symposium "The Environment and the industry", National Research and Development Institute for Industrial Ecology, Bucharest, 2015, p. 118-123.

[6] KLINEA, M., ESHLEMANA, K., GARLITZA, J., URENB, S., Atmos. Environ,, 226, 2016, p. 195.

[7] SAEIDI-MOBARAKEH, Z TAVAKKOLI-MOGHADDAM, R., MEHRZAD NAVABAKHSH, M., AMOOZAD-KHALILI, H., J. Clean. Prod., testing represents a proactive tool for long term management of different landfills.

behavior as a result of buffering capacity.

Regarding analyzed samples, D6 waste sample has a low buffering capacity. In these conditions, the hazardous properties and detailed studies must be performed to establish the optimum conditions for long-term storage. In conclusion, the wastes that have a higher buffering capacity such as D1, D2, D3, D4 and D5 samples are safer to store in the long-term condition, the impact on the environment being reduced.

Ministry of Research and Innovation.

252. 2020, p.

[8] YURRAMENDI, L., CABALLERO, S., PEREZ, S., Tenth International Waste Management and Landfill Symposium, Sardinia, Italy, October 2005, p. 1.

[9] Government Order no. 95 establishing acceptance criteria and preliminary procedures for the acceptance of waste storage and the national list of waste accepted in each class of landfill, Romanian Official Monitor no. 194 from 8th March, 2005. [in Romanian].

[10] GWANG SUK, Y., JI WHAN, A., GI CHUN, H., HEE CHAN, C., Korean J. Chem. Eng,, 23, no. 2, 2006, p. 237.

[11] CEN/TS 15364:2006. Characterization of waste. Leaching behavior tests. Acid and base neutralization capacity test.

[12] European Commission notice on technical guidance on the classification of waste, $(2018 / \mathrm{C}$ 124/01), O. J. from 09 April, 2018, p.98. 